\title{
Geological and hydrogeological controls on possible transboundary groundwater flow between Bulgaria and Greece
}

\author{
Victor Spasov, Aglaida Toteva, Marin Ivanov, Kalin V. Naydenov, \\ Tatiana Orehova, Aleksey Benderev
}

Geological Institute, Bulgarian Academy of Sciences, Acad. G. Bonchev St., Block 24, Sofia 1113, Bulgaria; e-mails:viktorspasov@abv.bg,aglaya.j@abv.bg.marin.ivanov@meteo.bg,k.naidenov@gmail.com, tvorehova@gmail.com,aleksey@geology.bas.bg

(Accepted in revised form: November 2017)

\begin{abstract}
A major issue in groundwater and surface water management and monitoring is transboundary groundwater flow between neighbouring countries. The subject of our study is the assessment of the groundwater flow across the state border between Bulgaria and Greece, which is characterized by complex natural features. We present a study on the factors that control the groundwater flow and formation, such as lithological composition, geological structure, topographic features, surface water network, etc. It was determined that, in most sections along the state border, the probability of transboundary groundwater flow is rather small, due to the position of the surface and groundwater divides. In the areas where the state border follows a ridge with fissured groundwater system, there are no prerequisites for transboundary flow. Groundwater flow is likely to occur only in the marble-dominated karst areas, as well as in the Quaternary or NeogeneQuaternary aquifers in river valleys that host porous groundwater bodies. The probability of transboundary groundwater flow could increase in response to certain human activities.
\end{abstract}

Spasov, V., Toteva, A., Ivanov, M., Naydenov, K., Orehova, T., Benderev, A. 2017. Geological and hydrogeological controls on possible transboundary groundwater flow between Bulgaria and Greece. Geologica Balcanica 46 (2), 97-102.

Keywords: groundwater body, transboundary flow, Bulgaria, Greece.

\section{INTRODUCTION}

After Bulgaria joined the EU in 2007, the Bulgarian legislation has harmonized with the European law, and the requirements of the Water Framework Directive 2000/60 (WFD, 2000) for water management based on river basin districts have been introduced. The basic territorial unit for groundwater management is "groundwater body" (GWB) that is defined as a distinct volume of groundwater within an aquifer or aquifers characterized by a particular groundwater status (Water Act, 2006).

About 170 groundwater bodies have been identified in our country, based on the hydrogeological and hydrological factors (see websites of the East Aegean River Basin and West Aegean River Basin Directorates: http://earbd.org, http://www.wabd.bg; see also Mihaylova et al., 2006). Some of them are adjacent to the state border and thus they may be named as "boundary" GWBs, where transboundary groundwater flow may occur. Some of them are adjacent to the state border, but no groundwater flow is occurring between them, and thus they may be indicated as "border" GWBs. If an underground flow exists between such adjacent bodies, then they are identified as "transboundary" GWBs. In fact, they are national components of a certain "transboundary aquifer". The aim of the present study is to assess the possibility of transboundary groundwater flow across the Bulgarian-Greek border.

\section{GROUNDWATER BODIES IN THE BULGARIA- GREECE BORDERLAND AREA}

Eleven Bulgarian groundwater bodies have been identified that are adjacent to the ca $500 \mathrm{~km}$ long state border between Bulgaria and Greece and, on the Greek side, there are eight groundwater bodies identified (Fig. 1). Only for several of the GWB is there full coincidence of their boundaries on both sides of the state border. The main characteristics of the Bul- 


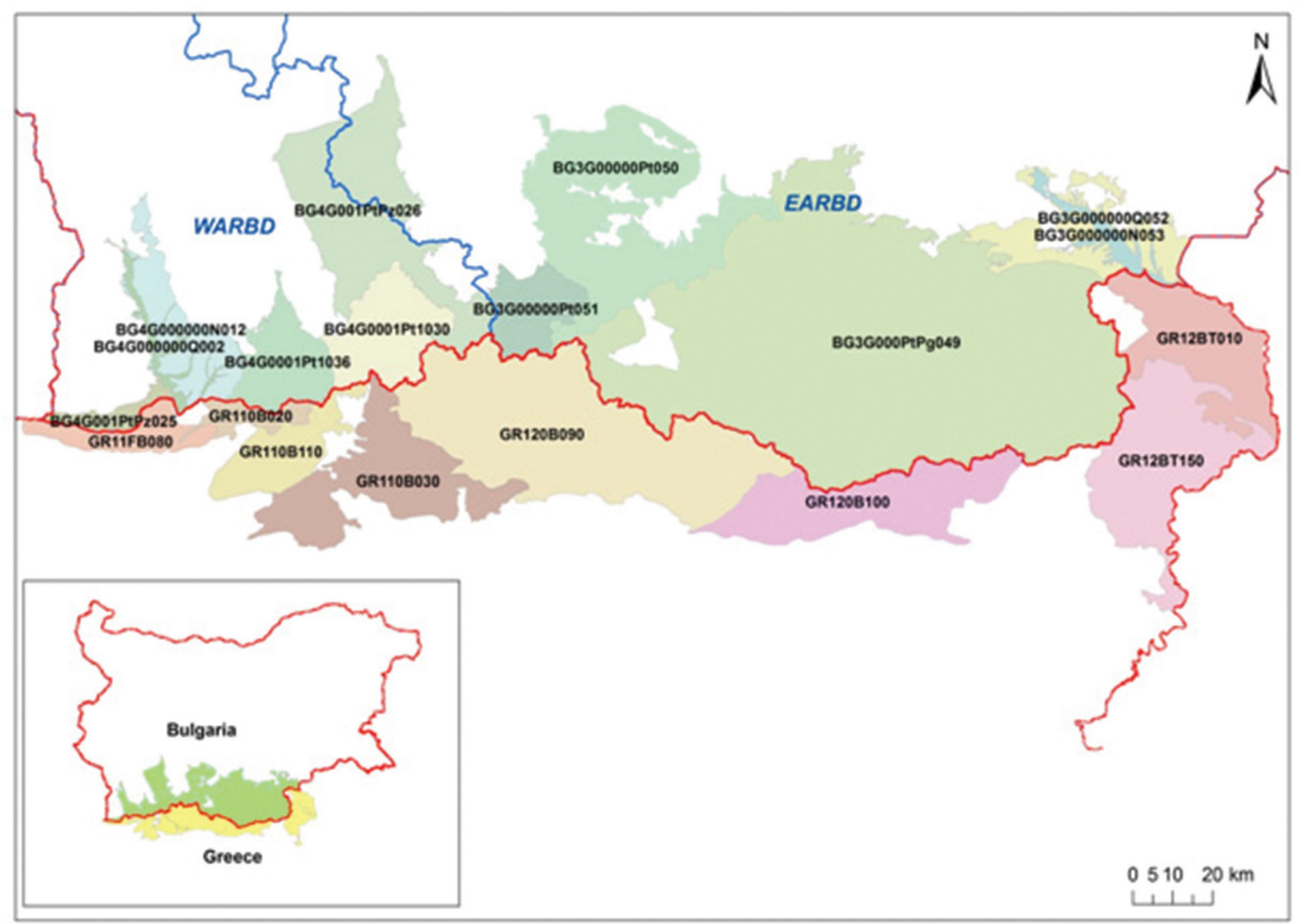

Fig. 1. Location of the GWBs along the state border between Bulgaria and Greece.

garian GWBs, including their area, type, quantitative and qualitative status, are presented on the web-pages of the West-Aegean and East-Aegean River Basin Directorates (Table 1). Their characteristics were complemented, based on activities in implementation of the Project funded by EEA Grants "Study of transboundary groundwater bodies between Bulgaria and Greece". The last geological maps in scale 1:50 000 were used to refine the geological structure for the respective GWBs.

Groundwater formed in the Bulgaria-Greece border area is an important source of drinking water for local population, mainly from tapped springs. Porous GWBs in alluvial sediments experience the highest anthropogenic pressure, due to intensive water use for domestic, agricultural and industrial activities in the large settlements, which are covered by the porous aquifer (groundwater abstraction mainly from boreholes).

The rocks outcropping on the territory of our country continue on Greek territory, and the rock type determines the type of the related groundwater collector. After delineation of the Greek GWBs, unlike Bulgaria, some of the territories are left blank, as they are considered insignificant from hydrogeological point of view. According to Panagopoulos and Stavropoulos (2015), from west to east these GWBs are:

- GR11FB080 Ano Poroia - Beles (with a length of the state border section of $33.61 \mathrm{~km})$;

- GR110B020 Agistro (27.72 km);

- GR110B110 Vrontous - Beles (14.08 km);

- GR110B030 Menikio - Falakro (5.92 km);

- GR120B090 Potamoi - Stavroupoli (100.59 km);

- GR120B100 Drosini (56.67 km);

- GR12BT0 Soyfli - Didimotich (7.08 km);

- GR12BT010 Orestiada (21.26 km).

Generally, the GWBs on Greek territory experience relatively low anthropogenic pressure, with the exception of GWB Orestiada GR12BT010, where groundwater is largely used.

\section{METHODOLOGY FOR IDENTIFICATION OF GROUNDWATER BODIES WITH TRANSBOUNDARY FLOW}

In order to identify the cross-border GWBs with possible transboundary groundwater flow, the specific features of the related areas should be examined and identified, with emphasis on the border sections: 
Table 1

Brief characteristics of Bulgarian GWBs close to the border with Greece

\begin{tabular}{|c|c|c|c|c|c|}
\hline Code & Name & Host-rocks' lithology & $\begin{array}{l}\text { Area } \\
\left(\mathrm{km}^{2}\right)\end{array}$ & $\begin{array}{l}\text { Length of } \\
\text { the border } \\
\text { section } \\
(\mathrm{km})\end{array}$ & $\begin{array}{l}\text { Groundwater } \\
\text { resources }(1 / \mathrm{s})\end{array}$ \\
\hline BG4G000PtPz025 & $\begin{array}{l}\text { Fissured ground- } \\
\text { water in Belasitsa } \\
\text { block }\end{array}$ & $\begin{array}{l}\text { Ortho- and paragneisses, schists, am- } \\
\text { phibolites and metaultramafic bodies; } \\
\text { granitoids }\end{array}$ & 132 & 41.38 & 82 \\
\hline BG4G000000N012 & $\begin{array}{l}\text { Porous groundwater } \\
\text { in the Neogene, } \\
\text { Sandanski Graben }\end{array}$ & $\begin{array}{l}\text { Conglomerates, weakly lithified sand- } \\
\text { stones, sands and clay sediments }\end{array}$ & 632 & 4.23 & 571 \\
\hline BG4G000000Q002 & $\begin{array}{l}\text { Porous groundwater } \\
\text { in the Quaternary, } \\
\text { Kresna-Sandanski }\end{array}$ & Gravels, sands and clay sediments & 122 & 4.23 & 271 \\
\hline BG4G0000Pt1036 & $\begin{array}{l}\text { Fissured-karst } \\
\text { groundwater in } \\
\text { Gotse Delchev karst } \\
\text { basin, Teshovo } \\
\text { pluton }\end{array}$ & $\begin{array}{l}\text { Marbles, ortho- and paragneisses, } \\
\text { schists, minor amphibolites } \\
\text { Neogene-Quaternary clastic sediments }\end{array}$ & 446 & 36.05 & 2704 \\
\hline BG4G0000Pt1030 & $\begin{array}{c}\text { Fissured-karst } \\
\text { groundwater in } \\
\text { Satovcha karst basin }\end{array}$ & $\begin{array}{c}\text { Ortho- and paragneisses, marbles, am- } \\
\text { phibolites, schists and ultramafic bodies; } \\
\text { deformed granitoids and gabbro-diorites; } \\
\text { minor volcaniclastic and siliciclastic } \\
\text { (Neogene-Quaternary) sedimentary } \\
\text { rocks }\end{array}$ & 599 & 46.59 & 1259 \\
\hline BG4G001PtPz026 & $\begin{array}{c}\text { Fissured ground- } \\
\text { water in the South } \\
\text { Bulgarian granites, } \\
\text { Western Rhodope } \\
\text { metamorphic rocks, } \\
\text { Barutin-Buynovo } \\
\text { intrusion }\end{array}$ & $\begin{array}{l}\text { Predominantly granitoids; minor gneiss- } \\
\text { es, marbles and amphibolites; minor } \\
\text { Neogene-Quaternary sedimentary rocks }\end{array}$ & 1407 & 23.56 & 1557 \\
\hline BG3G00000Pt051 & $\begin{array}{l}\text { Karst groundwater, } \\
\text { Nastan-Trigrad } \\
\text { karst basin }\end{array}$ & $\begin{array}{l}\text { Marbles, granites, minor gneisses and } \\
\text { schists; minor Paleogene and Neogene-- } \\
\text { Quaternary sedimentary rocks }\end{array}$ & 389 & 26.82 & 2835 \\
\hline BG3G00000Pt050 & $\begin{array}{l}\text { Fissured ground- } \\
\text { water in the Central } \\
\text { Rhodope area }\end{array}$ & $\begin{array}{l}\text { Variegated metamorphic complex (or- } \\
\text { tho- and paragneisses, minor marbles, } \\
\text { amphibolites, schists and ultramafic bod- } \\
\text { ies); subordinate volcaniclastic and sedi- } \\
\text { mentary rocks (Paleogene and Neogene-- } \\
\text { Quaternary); minor granitoids }\end{array}$ & 1658 & 8.84 & 2839 \\
\hline BG3G000PtPg049 & $\begin{array}{l}\text { Fissured water in } \\
\text { the East Rhodope } \\
\text { area }\end{array}$ & $\begin{array}{c}\text { Variegated metamorphic complex (or- } \\
\text { tho- and paragneisses, marbles, amphi- } \\
\text { bolites, schists and ultramafic bodies); } \\
\text { Volcanic-sedimentary complex } \\
\text { (Paleogene volcanic and volcaniclastic } \\
\text { rocks and Paleogene and Neogene-- } \\
\text { Quaternary coarse- to fine-grained si- } \\
\text { liciclastic sedimentary rocks with minor } \\
\text { limestones) }\end{array}$ & 6590 & 269.7 & 10693 \\
\hline BG3G000000Q052 & $\begin{array}{l}\text { Porous groundwa- } \\
\text { ter in Quaternary, } \\
\text { Svilengrad- } \\
\text { Stambolovo }\end{array}$ & $\begin{array}{l}\text { Sands and clay sediments, sandstones, } \\
\text { conglomerates and breccias with lime- } \\
\text { stone intercalations }\end{array}$ & 164 & 5.86 & 431 \\
\hline BG3G000000N053 & $\begin{array}{l}\text { Porous ground- } \\
\text { water in Neogene, } \\
\text { Svilengrad-- } \\
\text { Stambolovo }\end{array}$ & Gravels, sands and clay sediments & 705 & 19.85 & 965 \\
\hline
\end{tabular}


- lithological and structural features of the GWBs: unconsolidated sediments, lithified sedimentary rocks, magmatic (intrusive and volcanic) or metamorphic rocks and their stratigraphic and structural position;

- similarities in the geological setting and related GWB characteristics on both sides of the state border;

- in Bulgaria, the geological map in scale 1:50 000 was the primary source of information for the geological analysis;

- predominant type of groundwater: porous, fissured, karstic, and to what extent it can be considered representative for the entire GWB. Their delineation is based on analysis of the geological maps;

- geomorphological forms and relief along the state border. It is essential to determine whether there is a coincidence of the state border (as well as the GWB boundary) with rivers or surface water divides. This is done by analyzing topographic maps and DEM;

- groundwater recharge and discharge zones. Information on the location of these zones is useful for inferences concerning possibilities of the transboundary flow: from the recharge zone located in one country to the discharge zone in the neighbouring country. Such conditions are common in karst regions and highly permeable aquifers;

- direction of the groundwater flow. This factor is of particular importance for the low productive GWBs in the weathered zone (with thickness of several tens of meters) typical for mountainous areas. Groundwater flow direction follows the topographic slope towards the river network. In this case, the surface water and the groundwater divides generally coincide. In the case when the state border follows ridges in such mountainous areas, the groundwater exchange through the state boundary is not possible;

- possibility of change in the hydraulic gradient value and the groundwater flow direction as a result of human activities: from groundwater abstraction or other pressures that lead to change in the natural status of groundwater.

The assessment of the conditions and factors relevant to the determination of the presence or absence of transboundary groundwater flow was carried out, using the GIS and the complex geological database (Toteva et al., 2015).

\section{RESULTS AND DISCUSSION}

The first steps of the analysis are the construction of topographic and geological profiles along the Bulgarian-Greek state border and the localization of areas with porous, fissured and karst groundwater systems (Fig. 2). Different zones are identified and outlined in respect to the relationships between the state border and the hydrogeological conditions (main or secondary drainage divides or water courses).

It is established that the fissured groundwater systems formed in weathering zones dominate in the area along the state border (84\%). Porous and karst groundwater systems have much less coverage: about $8 \%$ each. Porous aquifers are related mainly to Neogene and Quaternary sediments that fill the grabens along the river valleys of the Struma and Maritsa rivers. Small isolated outcrops of porous sediments are considered inseparable parts of the fissured GWBs. The same approach refers to comparatively small bodies of carbonate rocks (marbles). The most important zone with a typical karst groundwater system is around the Slavyanka Mountain: the Gotse Delchev karst region (Antonov and Danchev, 1980). Relatively large outcrops of marbles are located in the region where the Mesta River leaves the territory of Bulgaria, but, due to weaker karstification, this aquifer should rather

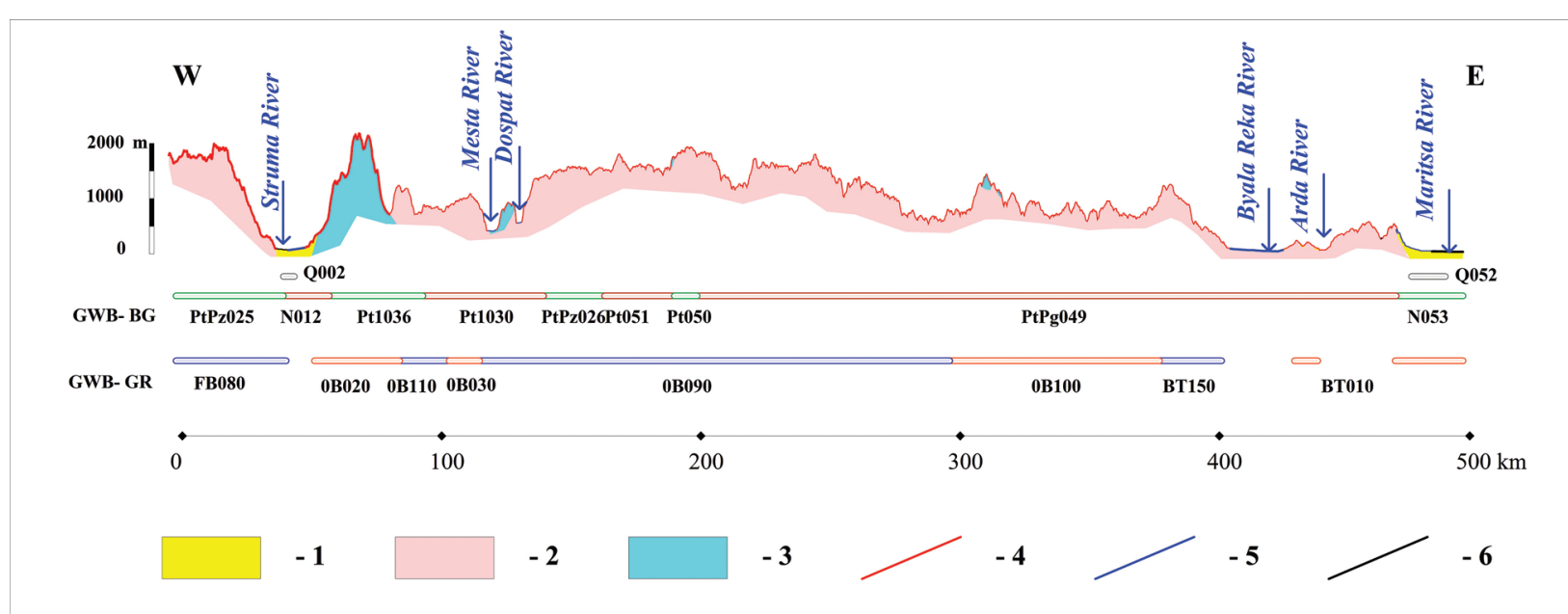

Fig. 2. Schematic profile along the Bulgarian-Greek border, showing location of the GWBs. 1 - Porous groundwater systems; 2 - Fissured groundwater systems; 3 - Karst groundwater systems; 4 - The state border follows main or secondary surface water divide; 5 - The state border follows a river; 6 - No hydrogeologically important boundary along the state border. 
be considered as a fissured groundwater system with comparatively high resources.

The groundwater types, along with the presence of hydrogeologically important boundaries, define the specific relationships between Bulgarian and Greek GWBs (Fig. 3).
The direction of the groundwater flow depends mainly on the presence and type of the hydrogeologically important boundary (mountain ridge or river) along the state border. For the most part, the state border coincides with the main and secondary water divides: about $85 \%$ of the total length. The predomi-

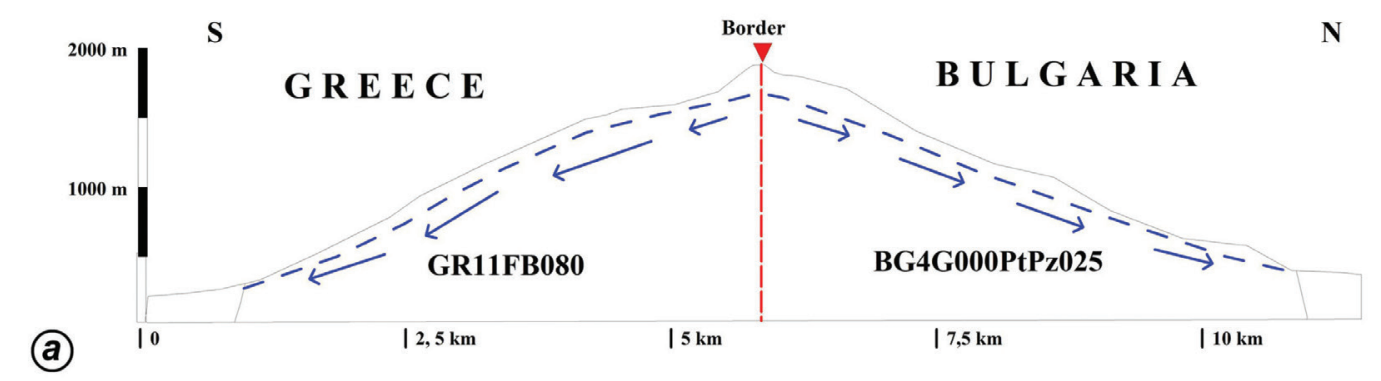

W

$\mathbf{E}$
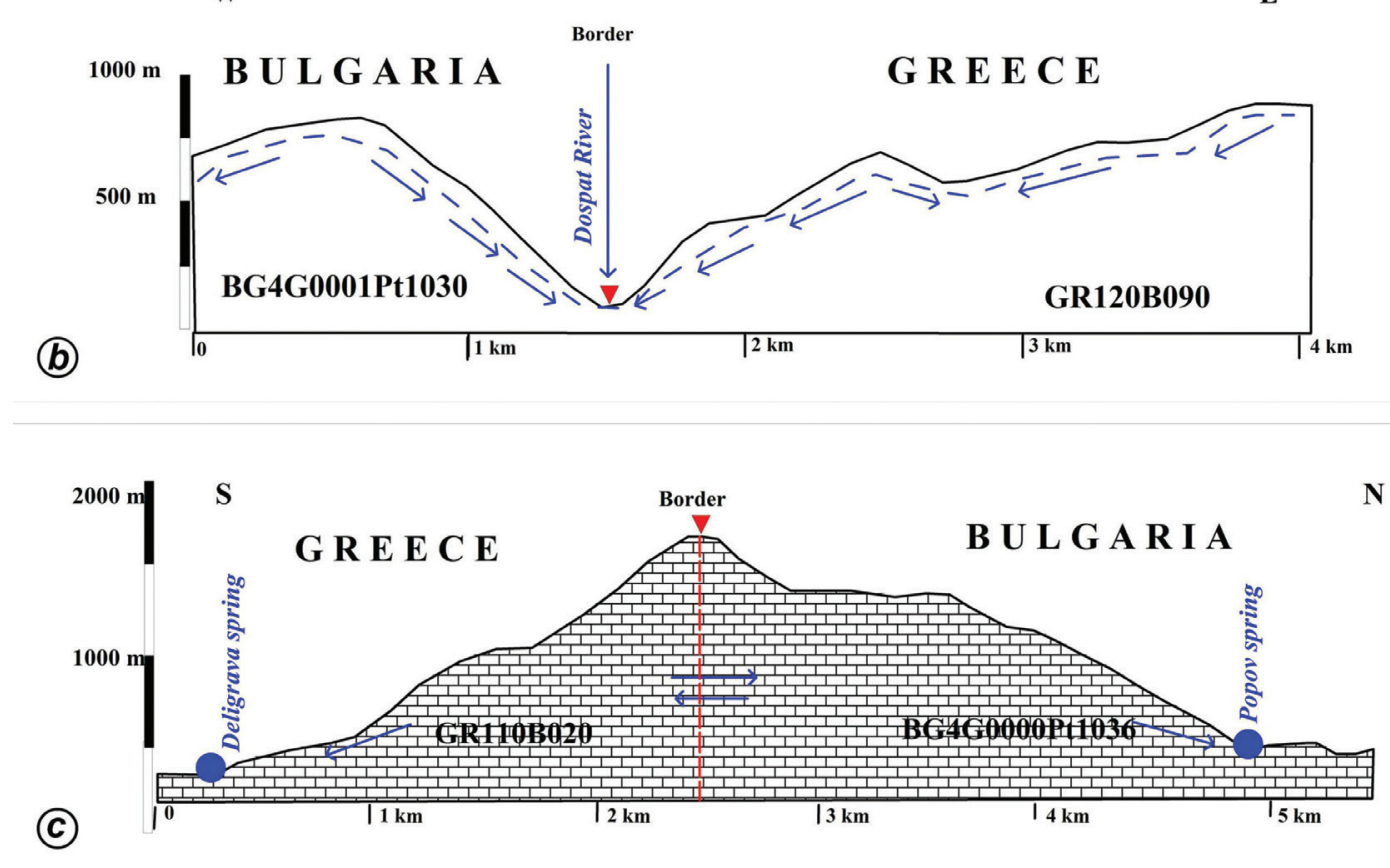

WN

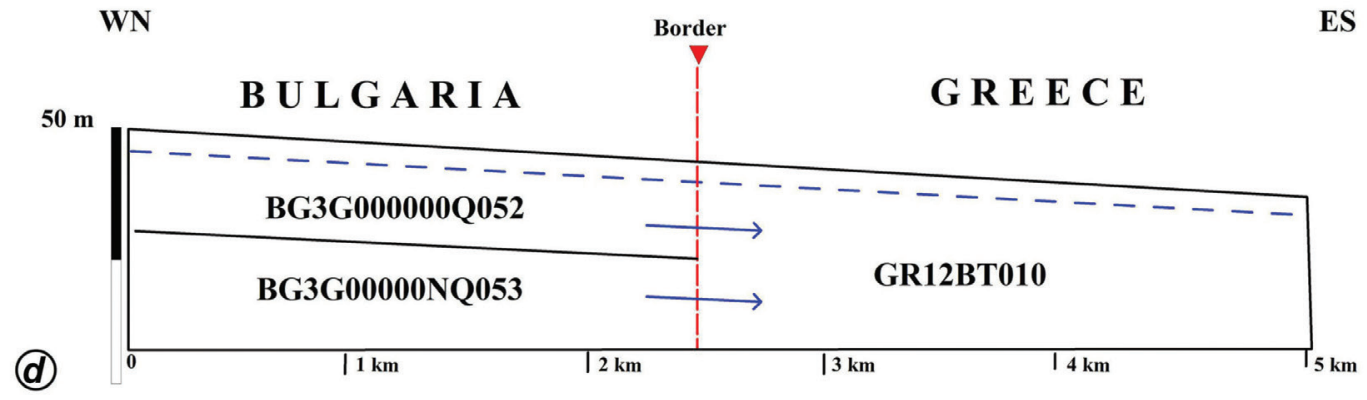

Fig. 3. Schematic cross-sections showing the hydrogeological settings at the Bulgarian-Greek border: a) the state border follows a mountain ridge: both surface water and groundwater divided (BG4G000PtPz025 and GR11FB080); $b$ ) the state border follows a river (BG4G0000Pt1030 and GR120B090); c) the state border crosses a karst basin (GR110B020 and BG4G0000Pt1036); d) the state border crosses a porous GWB (no hydrogeologically important boundary: BG3G000000Q052, BG3G000000N053 and GR12BT010). 
nant distribution of fissured groundwater systems in weathering zones predetermines the coincidence of the surface water and groundwater divides (Fig. $3 a$ ). In this case, groundwater flow across the state border is not possible.

The second case is when the state border follows a water course: tributaries of the Maritsa, Byala Reka and Struma rivers and, locally, the Mesta and the Dospat rivers. In these sectors, the groundwater is drained by the rivers (Fig. 3b), and therefore no transboundary groundwater flow can occur.

Only in very few sections within the river valleys, filled by alluvial sediments, does the state border not follow any hydrogeologically important boundary. The main groundwater flow in river valleys is toward the rivers and downstream. In such sectors, transboundary flow is possible.

In the karst regions, the groundwater divide typically does not coincide with the surface water divide. This is the case of the area around the Slavyanka Mountain, which has a pronounced karst character. Despite the fact that the state border follows ridges that are surface water divides, there are possibilities for transboundary groundwater flow across the Bulgarian-Greek border (Fig. 3c). According to the recharge conditions and the degree of karstification, transboundary groundwater flow is possible in both directions at different times. Additional anthropogenic influence (i.e., the construction of new boreholes in some of the drainage zones) may increase the transboundary flow.

In the areas where the state border crosses the valleys filled with Neogene and Quaternary sediments, and provided that there is no established hydrogeological boundary condition, there may be transboundary groundwater exchange. On the territory of both countries, porous aquifers are formed with a common groundwater level and a general direction of the groundwater flow from Bulgaria to Greece, as in the Maritsa River valley (Fig. 3d). It is noteworthy that in the Maritsa River valley in Bulgaria two hydraulically connected GWBs at different depths are identified (in Neogene and in Quaternary sediments), whereas on the territory of Greece they are united in a single GWB.

\section{CONCLUSIONS}

There is a significant difference in the number, size and hydrogeological characteristics of GWBs on both sides of the state border between Bulgaria and Greece. This is understandable, given that the GWBs are essentially administrative, water-management units and their delineation depends on the water policy concept in the respective country.

The obtained results unequivocally prove that, for most of the state border between Bulgaria and Greece, there are no prerequisites for a transboundary groundwater flow. Only for three out of 11 GWBs along the Bulgaria-Greece border area is there a possibility for groundwater flow across the state border. These are the two GWBs in the Maritsa River valley: BG3G000000Q052 (Porous groundwater in Quaternary sediments - Svilengrad-Stambolovo) and BG3G000000N053 (Porous groundwater in Neogene sediments - Svilengrad-Stambolovo), which make contact on Greek territory with GR12BT010 (Orestiada - GWB BG4G0000Pt1036). The groundwater body "Fissured-karst groundwater in Gotse Delchev karst basin", along with GR110B020 Agistro, forms a separate karst basin.

In order to quantify possible transboundary groundwater flow, as well as to evaluate the risk for quantitative and chemical status, it is necessary to carry out additional hydrogeological studies jointly by experts from Bulgaria and Greece. The obtained results would help to develop a common monitoring system and better groundwater management of the groundwater body.

\section{Acknowledgements}

The research was carried out in the frames of the Project "Study of transboundary groundwater bodies between Bulgaria and Greece" supported by Iceland, Liechtenstein and Norway through the EEA Grants. We are grateful to the Greek experts Panos Panagopoulos and Xenofon Stavropoulos, who provided information about the groundwater bodies on the territory of the Republic of Greece.

\section{REFERENCES}

Antonov, H., Danchev, D. 1980. Groundwater in the Republic of Bulgaria. Tehnika, Sofia, $360 \mathrm{pp}$. (in Bulgarian).

Mihaylova, B., Gorova, R., Benderev, A. 2006. Some problems concerning delineation and characterization of groundwater bodies in Bulgaria. Proceedings of the Conference on $\mathrm{Wa}$ ter Observation and Information System for Decision Support BALWOIS 2006, Ohrid, Republic of Macedonia, 8 pp.

Panagopoulos, P., Stavropoulos, X. 2017. General Report on Greek-Bulgarian ground water bodies. Annex 18. Project „Study of transboundary groundwater bodies between Bulgaria and Greece". European Economic Area Grants, 48 pp. (unpublished report).

Toteva, A., Benderev, A., Gorova, R., Mihaylova, B., Trayanova, M., Babukchieva, M., Grozeva, D., Grozeva, P.,
Galitova, D., Mitseva, V., Argirova, E., Osev, S. 2015. Organization of information provision and support for characterization of groundwater bodies in states' boundary areas Bulgaria-Greece. Bulgarian Geological Society, National Conference with International Participation "Geosciences 2015”, Abstracts, 149-150 (in Bulgarian).

Water Act 2006. Promulgated in State Gazette, 67 (27.07.1999), last amended and supplemented, State Gazette, 12 (03.02.2017), 171 pp. (http://www5.moew.government. bg/?wpfb_dl=16390).

WFD 2000. Directive 2000/60/EC of the European Parliament and of the Council of 23 October 2000 establishing framework for community action in the field of water policy. $O f$ ficial Journal of the European Communities L327, 1-71. 